\title{
Returning to Haifa as Political Discourse and a Potent(ial) Source of Controversy
}

The present issue of [sic] investigates cultural forms that work against monumentalization of literature as conceived by the notion of the static literary canon. [sic]'s ostensibly Lukácsian approach grasps literature (along the Marxist vein) as a catalyst or as a call to action. The subject of the following discussion, Returning to Haifa written in 1969 by Ghassan Kanafani, offers up the author's voice representing his politicized position within Palestinian culture and history. Within a newly evolving nationalist Palestinian literature - independent from other Arabic national or canonical Islamic texts - Kanafani's writing has provided a framework and impetus for questioning accepted hierarchical notions of Palestinian governance; that is, the unequal relationship between the Palestinians in exile, in the territories and in Israel. Thereby his novella problematizes both generally accepted Palestinian and Israeli-Western morality that serves to buttress intransigent though commonly held positions. Bringing together differences raises ambiguities of received understanding. The power of change is thus signalled both by the plot and discourse of the novella. Returning to Haifa is a novella that is valuable literarily - both intrinsically (the quality of his style has been compared to James Joyce' $\mathrm{s}^{[1]}$ ) and for its transcultural and transnational implications. Nonetheless, its ideological claims threaten to overshadow its literary, narrative complexity. Through a number of interrelated plots concerning return and a sustained examination of the problematic metaphors of home and land, Returning to Haifa concerns the impact of Palestinians who had fled during the 1948 war with Israel returning in 1967 (when the borders between what was formerly the Jordanian West Bank and Israel were reopened). In the novella, a Palestinian couple returns to Haifa in 1967 to see their former house again and to discover what became of their five-month-old baby Khaldun whom his Palestinian mother Safiyya left behind when she and her husband Said S. fled the chaos and danger caused by Britain's sudden evacuation of its 
Mandate for Palestine in 1948. After fleeing war torn Europe, a Jewish couple Iphrat and Miriam Koshen were assigned the house so long as they would adopt its Arab infant inhabitant.

The text bears political and ideological significance. Its author Ghassan Kanafani, a figure of political suasion within Palestinian culture and specifically its literary corpus, was killed by a car bomb activated by Israeli Mossad agents in Beirut in 1972 in retaliation for his leadership role in the Marxist Popular Front for the Liberation of Palestine, which was responsible of organizing the Lod Airport Massacre earlier in 1972 that resulted in dozens of people killed or injured. The PFLP, the second largest of the groups forming the PLO (in the 1970s), hired a hit-squad of Japanese Red Army mercenaries (paid terrorists) for the attack. Returning to Haifa describes a politics of reclamation and it figures in a receptive field where confrontational politics - arguably including revenge - against Zionism is understood.

Through its complex, open-ended story and its narrative sophistication effectively employing voice, imagery and literary realism, Returning to Haifa is a text that appeals not only to the Palestinian and larger Arab community, but also interests a more diverse university-educated community, including many (Western) Jews ${ }^{[2]}$ Though Kanafani saw his work as "resistance" writing (Riley and Harlow, "Introduction" 13-14) ${ }^{[3]}$, he states in an interview that his project goes beyond reporting and probing Palestinian issues set against the past 1948 topography: "At first I wrote about Palestine as a cause in and of itself.... When I portray the Palestinian misery, I am really presenting the Palestinian as a symbol of misery in all the world" ("Introduction" 24). Several interrelated issues stem from Kanafani's powerful transcultural circulation of the trauma of war and dispossession vividly described through the characters' memory. Four characters encounter each other and the past, though Palestinian Said S. "hadn't counted on the [repeated] memory coming back full of the same insane turmoil that rightfully belonged only to the actual moments of the experience itself [of his exodus from Haifa in 1948]" (Kanafani 156) ${ }^{[4]}$. In the context of Said S.'s return to Haifa, the present (in the story, after the 1967 war) rejoinders the past revealing unresolved painful memories that trigger political claims.

Viewing literature as a social construction emphasizes its role as an instrument conveying ideology, and potentially challenging it. Accordingly, Returning to Haifa describes the contours of Palestinian history between 1948 and 1967, and promotes a discursive model for Palestinian 
resistance, while probing the effects of this strategy and its implications. In the wake of Kanafani's death by assassination - construed by his Palestinian followers as martyrdom - and his widow Anni Kanafani's establishing the charitable Ghassan Kanafani Cultural Foundation in his memory and actively managing the copyright for his writing, the novella and his other work are deployed eliciting further ideological implications.

As "travelling trauma" text, the drama-infused novella has the effect of sharpening consciousness by inviting debate to broaden "implacable" historical positions ("Introduction" 15). Through its narrative instancing of discussion across geopolitical borders, Returning to Haifa has significance for a cosmopolitan readership invested in contemporary Middle Eastern issues. While the work ends with appeals to violence, its characters' aspersions are toward inevitable dialogue; immediately Miriam recognizes Safiyya and Said S.: "I have been expecting you for a long time... You are the owners of this house. I know that" (Palestine's Children 163). This sense of inevitable engagement between past and present occurs also in the important foil story where another Palestinian called Faris al-Lubda returns to Jaffa (after twenty years in exile, just like Said S. and Safiyya). Faris discovers his home has been rented for decades to an Arab couple who remained in Israel after 1948. Uncannily echoing the Jewish woman Miriam's welcome to Said S. and Safiyya in Haifa, the unnamed Arab tenant in Jaffa says in greeting to Faris: "Come in, sit down. We need to talk a little. We've been waiting for you a long time" (176).

Determining who has governance over dispossessed property (symbolizing the nation) is "a cause" as material in 2011 seen through the omnipresent symbol of the house key in Palestinian demonstrations, as it was in 1969. For example, the dialogistic novella bears the potential to contribute to current human rights discussion: Barbara Harlow (Kanafani's principal translator) views the contemporary “'geographies of struggle'...represent[ing] the transformations and reversals that have resulted from... the historic move - political, discursive, critical - from interrogation and assassination to negotiation...'resistance literature' is discovering... other, alternative narrative possibilities in the paradigmatic contradictions on the grounds of human rights' reporting... [that] entails both documentation and intervention" (Harlow 153). Thereby Kanafani can be interpreted representing realistically the topographical map of the past but continuously 
changing Palestinian-Arab locations, while querying the implications of his and others' (including his characters') post-1948 constructions.

In the spirit of Jewish American Daniel Barenboim and Palestinian Edward Said's friendship and partnership in writing a treatise on music, culture, anti-Semitism and the Middle East called Parallels and Paradoxes: Explorations in Music and Society, Kanafani's Returning to Haifa offers a model for face-to-face negotiation of differences, rather than division envisaged by a two-state Palestinian-Israeli solution. Furthermore, in Muhammad Siddiq's view, "The question of the... adversary... assumes dimensions of a moral dilemma in... Returning to Haifa" (37). Both in the refugee camps - where schools exist in memory of Kanafani, who was a teacher before becoming a writer - and among Western elites in the diasporic metropolis, Kanafani is credited (by Radwa Ashur) with "portray[ing] Jewish characters as sensitive human beings rather than as caricatures of the enemy" ("Introduction" 24). For example, one of the ways in which the novella builds sensitivity toward Miriam is by constantly referring to her as "the old woman," thus representing her as nonthreatening and accentuating her world-weariness. Additionally, characters such as Said S. challenge each others' intractability. The fairness of Kanafani's rendering of the issues and people involved in the Israeli-Palestinian conflict is further enhanced through shifting focalization between characters that serves to break down defensive stock responses in the reader.

Kanafani's novella is one of many moving stories from his Palestine's Children: Returning to Haifa and Other Stories foregrounding flashpoint issues relating to national fortunes of war that impact the lives and futures of children. The child's pivotal perspective is identified by Siddiq who incorporates Khaldun's (Said S.'s son whom the Jewish parents rename Dov) retort to Said S. (which Said S. then interprets) about man being a cause in the title of his critical assessment of Kanafani's brief life and literary career: Man is a Cause: Political Consciousness and the Fiction of Ghassan Kanafani. The naming of the children is significant. I use the combined name Khaldun/Dov to reflect the way in which his identities have been managed as a result of childrearing into the making of himself as "a cause." Depending on interlocutor or implied circumstance, in the novella he is referred to as either Khaldun or Dov. Khaldun is "derived from the... three-letter Arabic root, kh-I-d, meaning 'to remain' or 'last forever., ${ }^{\text {‘5] }}$ 
An unnamed Palestinian Jaffa couple named their son in honour of Faris al-Lubda's brother Badr who was killed in the April 1948 conflict, as is conventional. Signifying light against darkness, Badr's name in Arabic means "full moon"; Dov's name in Hebrew means "bear," conveying vulnerability, but also combative strength. Siddiq's study employs Khaldun/Dov's secondgeneration insight - agreed to by Said S., who contends, "Isn't a human being made up of what's injected into him hour after hour, day after day, year after year?" (Palestine's Children 183). Delineating a context for interpreting Kanafani's contribution to Palestinian culture and ongoing struggle, Siddiq's criticism draws out the implications of remembering the past - signified by khaldun - and having the power to secure the present - implied by the name dov. Kanafani's early contribution to Palestinian nationalist literature can be read as preserving the social rhetoric of his adult life that emphasized dissent, assassinations and death penalties, and amnesty; yet, his multivalent inquiry into the conditions of Arabs and Palestinians within Israel and his discursive, interrogatory style additionally probe these earlier claims and actions as purveying a self-limiting identity politics that is understood in Marxist terminology as ideological false consciousness. Emphasizing lived experience and the literary implications in After Lives: Legacies of Revolutionary Writing, Barbara Harlow investigates the reception of Kanafani's journalistic and fictional writings through the prism of his own biography as enigmatic "martyred" resistance fighter: "For those writers who... were assassinated, the combined issues of exhuming the corpse and examining the corpus weigh heavy on their legacy to the 'political movements' and their adherents" (16). In this way, Kanafani not only writes a Palestinian history, but the significance of his body of work is itself defined by the tragedy of his death within the unfolding Palestinian struggle.

Comparable to Joyce's modernist A Portrait of the Artist as a Young Man, Returning to Haifa expresses Kanafani's strong individual characteristics: his distinctive personal sensibilities, voice markings, a relationship to social anxieties expressed through his mapping of historical Palestine, and his individual role in expanding the boundaries of acceptable discourse by dialogically querying both obsolete externally imposed moral norms and values, and internal ones potentially within the grasp of Palestinians to control.

As with respect to subjective narrative specificity, first, Returning to Haifa processes deeply historical themes of home, land, and return broadly shared by Israelis and Palestinians. In the 
context of the story, the answer to Said S.'s repeated question - "What is a homeland?" ( Palestine's Children 184) - is forward thinking. Said S. concludes, "The homeland is where none of this [exile and dispossession] can happen... Palestine is something worthy of a man bearing arms for, dying for... We were mistaken when we thought the homeland was only the past... the homeland is the future" (186-87). Thus Said S. disavows the "worthless whip he used to call fatherhood" (182) in favour of the newly shaped and renewed passions of the younger generation. Through doubling - Khaldun/Dov, Khaldun/his siblings Khalid and Khalida, Faris/his brother Badr, this deceased brother Badr/the boy named in his honour - the fictional text preserves the tension between the past and future throughout. This tension is revealed in the handling of a photograph of Badr, Palestinian Faris al-Lubda's brother who was "martyred" in April 1948 in Jaffa. When Faris returns in 1967 he encounters the framed photograph through which the past erupts "draped in black" (175) hanging on the wall of his former house in Jaffa. The current Arab resident rented the house from the government after seeing "the picture, I found consolation in it, a companion that spoke to me, to remind me of things I could be proud of [the past, before 1948], things I considered to be the best in our lives" (176). On this basis, he "decided to rent the house" (176). The memory of Badr that has helped him "to resist but also to remain" is part of his existing family (177). The man and his wife Lamia and their sons Saad and Badr include the photographic brother (biologically Faris') as part of their "one family" (177). When Faris removes the photograph intending to take it home with him to Ramallah, thereby leaving "a disturbing void" on the Jaffa wall, he feels obliged to return it the next morning: "the picture [like Kanafani's fiction that marks significant historical moments is a] bridge to us [Israeli Arabs] and our bridge to you [Palestinians in the Occupied Territories]" (177) ${ }^{[6]}$

In reference to a personal narrative specificity, second, Returning to Haifa accentuates issues of natural right and blood relation (within the nature versus nurture philosophical debate) in relationship to the struggle for homeland. In this connection Said S. interprets Khaldun/Dov's posturing as having the effect of "watching a play prepared ahead of time in detail" (179). Thus Kanafani intertextually adapts the plot and the import of Brecht's The Caucasian Chalk Circle, notably "The [post-Nazi] Struggle for the [disputed] Valley" (Brecht 3-8), "The Noble Child" (9-25), and "The Story of the Judge" (61-83) who must adjudicate in "The Chalk Circle" (83-97) between 
Grusha and Natella. Grusha, a young peasant woman, takes on the responsibility and risk for a baby left behind in war by his birth mother, Natella, the wife to Governor Abashvili (who is beheaded in the tale). The judge determines Grusha, who "brought him [the child] up according to my best knowledge and conscience" (88), a 'better mother' than his natural parent. Adzak the judge, a commoner - "A poor man judg[ing] the poor/... on the wreck of justice/He brought them safe to shore" - finds that, in order "To feed the starving people/He broke the laws like bread" (80). "[T]he people... did not forget him and often remembered/His time of Judgment as a brief/Golden Age that was almost just" (96, emphasis added). Natella, the child's birth mother, contests with Grusha, the caregiver mother, within the chalk circle the judge drew by twice pulling the very young child towards her, thereby risking his injury or death. Grusha letting go of the child rightly affirms her "maternal" love. The judge further rewards her honour by dissolving a fraudulent marriage made during conflict in order to protect the child, so she can marry her pre-war love with whom she will raise the adoptive son. The Singer in The Caucasian Chalk Circle proffers "the meaning of the ancient song" or story in these final words to the play:

... what there is shall belong to those who are good for it, thus

The children to the maternal, that they thrive;

The carriages to good drivers, that they are driven well;

And the valley to the waterers, that it shall bear fruit. (The Caucasian Chalk Circle 97, emphasis added)

Aside from the house in Jaffa that Faris visits, the primary (theatrical) setting of Returning to Haifa is the family living room of a house in which both an Israeli adoptive mother Miriam and a Palestinian birth mother Safiyya have lived. Their meeting results in an abrupt, dislocating scene of transcultural interchange between strongly defined figures, whose history, interests and thereby conclusions diverge. Their difficult dialogue challenges by example any self-referential ideological claims involved in taking-up-sides by the reader both at its time of writing and now. This model of exchange between the mothers and Said S. and Khaldun/Dov is credited by F. Mansur as "the first 
time [in Arabic literature] the Palestinian and the Jew meet each other, not on the battlefield but in a normal room, where each of them puts forth his point of view and discusses it with the other" ("Introduction" 25). Editors Riley and Harlow conclude, "The discussion is as thought-provoking to the reader today [2000] as it was to the Palestinian community at the time it was written" (25).

Third, in terms of narrative specificity reflecting on acculturation, literary devices such as personification of stark, opposing ideological positions shaped by and shaping a wider highly charged and conflicted political arena are conveyed through use of irony and voice. Ironically, the son Khaldun does not define Said S. and Safiyya as his parents. Rather he claims to Miriam, "I don't know any mother but you" (Palestine's Children 179). Western readers familiar with the Exodus story will recognize Miriam's moral role as the faithful sister, who protects the infant Moses' safety, and cleverly has him cared for by his birth mother Jochebed (unbeknownst to him or anyone else), from whom he learns his sustaining Jewish cultural roots. Though ambivalent toward natural right, the Moses figure Khaldun/Dov is a complex prototype for the second-generation children of Palestinians and Jews impacted by the 1948 chaos and exodus during the formation of the state of Israel. Khaldun/Dov is altered after being confronted by his intercultural positioning; Said S. recognises: "surely he's lost himself after all this. He'll never be the same as he was an hour ago" (183). Like the acculturating role of Moses' wet nurse, but actual mother, the living room dialogue prepares Khladun/Dov for taking a leadership role. Said S. rejects Khaldun/Dov's accusation that he is "on the other side" (180) of the Palestinian-Israeli conflict from himself. Said S. counters: "Do you want to negotiate, or what?" (181). Yet, to see battle, Khaldun/Dov joins the Israeli Defence Force (IDF) Reserves (182), so the prospect of his taking up arms is imminent, but not yet his experience.

Kanafani manipulates second-person singular and plural voice by which the characters' declarative words communicate individual and projected nationalist positions - both Palestinian and Israeli. Riley and Harlow explain, "in the fourth and fifth chapters of the novel, Kanafani several times uses the second person plural (Arabic has a singular, dual, and plural in the second person), a device that denotes that the speaker is addressing his statements rhetorically to the Palestinian [or Israeli] community in general rather than to the one or two specific individuals" ("Introduction" 27, note 6). This doubling of voice occurs, for instance, in the scene in the Jaffa house quoted above ("We've 
been waiting for you a long time" [Palestine's Children 176, emphasis added] and in relationship to Faris taking the photograph of his brother Badr back with him to Ramallah - "I [the house resident] said to my wife if you wanted to reclaim him you'd have to reclaim the house, Jaffa, us..." [177, emphasis added]). Similarly, when Khaldun/Dov argues with Said S. over the notion of a homeland, Said S. refers to Miriam and Iphrat also by using the second-person plural. "Said, in response to Dov's condemnations moments before, is now addressing the Jewish community as a whole" (196, note 37$)$. The lines in the story resonate: "When are you going to stop considering that the weakness and mistakes of others are endorsed over the account of your own prerogatives? These old catchwords are worn out, these mathematical equations are full of cheating" (185-86, emphasis added).

Finally, fourth, in the example of the photograph's movement, Returning to Haifa proffers a powerful message about the complex psychological interplay between conceptual border crossing and armed struggle. Iphrat and Miriam Koshen who survived Auschwitz arrived in 1948 in Haifa where they were assigned a house by the Bureau of Absentee Property (part of the Jewish Agency) so long as they would adopt its Arab infant inhabitant. Miriam and Iphrat raised this child (Khaldun, whom they renamed Dov) as their own - as an Israeli Jew. In Khaldun/Dov's words, "From the time I was small I was a Jew... Even when they told me - later on - that my original parents were Arabs, it didn't change anything... After all, in the final analysis, man is a cause [rather than biological offspring socialized into predictable cultural and political formations]" (181). Dichotomized "causes" such as Zionism and Arab nationalism or Islam and Judaism are dismissed "for gauging the soundness of political consciousness or as a proper framework [in Khaldun/Dov's experience] for political action and solidarity" (Siddiq 45).

Khaldun/Dov's conclusion countervenes his birth mother Safiyya's naive presumptions that, when "naturally" given a chance "to decide" his future, he "will choose his real parents. It's impossible to deny the call of flesh and blood" (Palestine's Children 172). As with juggling the ownership of the evocative photograph of Badr, "martyred for the sake of his country's independence" (175) in Jaffa in the three-way 1948 struggle between Arabs, Jews and the British ${ }^{[7]}$ Khaldun/Dov, resistant to sentimentality, employs rationality to challenge the Palestinian birth parents' humanity: "We need to talk like civilized people [emphasis added]... How could a father and mother leave their five- 
month-old son behind and run off? How could a mother and father not his own raise him and educate him for twenty years?" (181-82). In the end, the Palestinian couple again leaves behind Khaldun/Dov - in effect, their lifeblood. Said S. says, "We always thought we'd find you, even if it took twenty years. But it didn't happen. We didn't find you, and I don't believe we will find you" (182).

The young man's biological parents returning after decades are especially shocked to find their first-born grownup son confident in his Israeli Defence Force uniform, which obviously represents a threat to Palestinians. Said S. rejects that Khaldun/Dov could have been born to Safiyya as "utterly impossible" (184); instead he lifts the taboo he posed against his other children engaging in armed struggle. Said S. now says he hopes his other "son", Khalid, has in his parents' absence joined the fidayeen; Khalid is Khaldun's namesake, but no longer considered a "brother" to him (182)[8] Throughout Said S. expresses the threat that Palestinians in the model of Khaldun's brother Khalid (and Faris al-Lubda, the protagonist of the foil plot who returns the photograph to Jaffa, before returning to Ramallah in order to join the fidayeen - "he's carrying arms" (178)) will return from exile in Ramallah and elsewhere to win back through "war" their home lost in the turmoil over the creation of Israel.] In the following passage accen ${ }^{[10]}$ tuating war through emphasizing "our" and possibly alluding to "settle[rs]," Said S. concedes: "You two [Miriam and Khaldun/Dov - his father Iphrat was killed in 1956 in the Suez Campaign] may remain in our house temporarily. It will take a war to settle that" (187) ${ }^{[11]}$ Thus Kanafani's story registers on at least two axes - Western and/or Israeli, and Palestinian. Ethical dilemmas of justice wanting resolution are raised for Western readers through the biblical allusion to Cain and Abel - in which a "remaining" brother (Khalid) might potentially kill his sibling (the "bear," soldier) Dov. 1970 arguments for the imperative of Palestinian armed conflict are accentuated in the novella.

Kanafani's brief career as a teacher, then a journalist, and then at the same time a newspaper editor and fiction writer holds a distinct position within Palestinian cultural history; in the specific example of Returning to Haifa, his individual contribution to Palestinian literatures extends further, beyond the ramifications of interpreting the open-ended novella. A film and many play versions of the novella exist. Utilising other formats than the novella as a book, these media extensions break down preconceived interpretive patterns embedded in narrative forms that bear their own 
ideological assumptions and implications. So, while the novella ends ambiguously, the play versions resolve the threatening disquiet (pertaining to the characters' futures) of the ending that advocates by the characters' words - on the surface - for an armed conflict, but by example through unprecedented intercultural dialogue - for a negotiation. Newspapers regularly review productions of the adaptations for theatre of Returning to Haifa whether it is being performed in Lebanon or in the middle of America: reviews accentuate the playwrights' various attempts to resolve the novella's ambiguous ending. Resolving the implacable positions the novella sets out in dialogue is itself ideological - for instance, in a Beirut production emphasizing the need for armed conflict or in a recent Jaffa production promoting dialogue ${ }^{[12]}$ Also, the play performances extend the performative dimensions (suggested by the intertextual allusions to The Caucasian Chalk Circle), which the novella cannot enact in the same way. However, in the spirit of Joyce's A Portrait of the Artist as a Young Man, the novel explores the character development especially of Khaldun/Dov, in relationship to historical location, as Joyce did in his Portrait and Dubliners. Currently Kanafani's fiction can also be heard being read aloud on the Internet where in one example on You Tube a renowned novelist, cultural critic and art theorist John Berger reads Kanafani's story "Letter from Gaza." In the preamble to this 2008 reading that took place at the Palestinian Literary Festival, Berger says he dedicated his most recent novel to the memory of Kanafani ${ }^{[13]}$ Academic critics, notably Harlow and Siddiq, have taken up the important project of providing in-depth explication and critique of Kanafani's brief life's work. The life of Kanafani's fiction in translation is likely to be enduring as a consequence of these scholars' efforts to address his individual talents for engaging a people's complex and evolving story.

\section{Works Cited}

Barenboim, Daniel, and Edward Said. Parallels and Paradoxes: Explorations in Music and Society. NY: Pantheon, 2002. Print.

Brecht, Bertolt. The Caucasian Chalk Circle. Trans. James and Tania Stern with W. H. Auden. Ed. John Willett and Ralph Manheim. London: Methuen Drama, 2000. Print.

"Changing the End to Ghassan Kanafani's 'Return to Haifa." Arabic Literature (In English). Jan. 8, 
2011. May 6, 2011 http://arablit.wordpress.com/2011/01/08/changing-the-end-to-ghassankanafanis-return-to-haifa/>. Web.

Harlow, Barbara. After Lives: Legacies of Revolutionary Writing. London: Verso, 1996. Print.

“John Berger reads Ghassan Kanafani's ‘Letter From Gaza.” Dec. 30, 2010. May 6, 2011 http://www.youtube.com/watch?v=_msusYXQlfc>. Web.

Kanafani, Ghassan. Palestine's Children: Returning to Haifa and Other Stories. Trans. Barbara Harlow and Karen E. Riley. Boulder, CO: Lynne Rienner, 2000. Print.

Riley, Karen E., and Barbara Harlow. "Introduction." Palestine's Children: Returning to Haifa and Other Stories. 2000. 13-28. Print.

Siddiq, Muhammad. Man Is a Cause: Political Consciousness and the Fiction of Ghassan Kanafani. Seattle: U of Washington P, 1984. Print. 
[1] Muhammad Siddiq 38.

[2] So, for example, I was first introduced to Kanafani's work through Marianne Hirsch's plenary address "Narratives of Return" at the International Society for the Study of Narrative annual conference held in Austin Texas, May 1-4, 2008.

[3] Hereafter cited parenthetically as "Introduction" in the text.

[4] Hereafter cited parenthetically as Palestine's Children in the text.

[5] Palestine's Children 191, note 8.

[6] In the corresponding main plot, a photo of Safiyya and Khaldun represents memory for Said S.: while trying not to be swept into the spring 1948 flow of humans toward the Haifa port, "In his head was one picture only, suspended as though hanging on a wall: his wife Safiyya and his son Khaldun" (155). Comparable to the commemorative photograph of Badr, this photograph represents irrevocable loss; another photograph, one of Said S. and Safiyya's personal possessions left behind - of Jerusalem before 1948, seen again in Miriam's living room - may represent cause for a political challenge or a call to arms.

[7] "Manshiyya: Arab residential quarter in Jaffa, the center of strong and well organized resistance.... The British remained in Jaffa for about a week after their withdrawal from Haifa. Wanting to avoid a repetition of the mass panic and exodus that had just taken place there, they sent reconnaissance planes over the Manshiyya to survey the Irgun [Jewish] positions and later bombed them. In the final days of April and the first of May 1948, fierce fighting took place among the three factions, with the result that the quarter was almost completely destroyed" (Palestine's Children 194-95, note 27).

[8] Khaldun and Khalid and a sister Khalida's names are "derived from the same three-letter Arabic root, kh-I-d" (Palestine's Children 191, note 8). The Jaffa couple named their son in honour of the fallen Badr, as is conventional. Khalid and Khalida's names are derivative, signifying the parents' remembrance of their son-left-behind and their hope of finding him alive; nonetheless Safiyya and Said S.'s relationship to the 'lost' son is confused or ambivalent. Said S. refers to himself as Abu Khalid (father of Khalid) (159), thereby recognising Khalid as his first-born son (Khaldun is thus 
presumed dead or in effect deceased). Also, at a significant moment in the story, Safiyya is referred to as Umm Khalid (mother of Khalid, rather than Khaldun), thereby conveying her lost immediacy with the memory of the actual first-born Khaldun (162).

[10] I appreciate having had the opportunity to rehearse these thoughts in a paper "Navigating Loss by Returning to Haifa," as part of the Cosmopolitan Memory and Travelling Trauma seminar at the American Comparative Literature Association meetings in Vancouver, March 31-April 3, 2011.

[11] In the Sinai war of 1956, "Israel invaded the Sinai Peninsula after Egyptian president Gamal Abdel Nasser nationalized the Suez Canal and closed it to Israeli and other foreign shipping" ( Palestine's Children 195, note 33).

[12] See, for example, "Changing the End to Ghassan Kanafani's 'Return to Haifa."”

[13] See “John Berger reads Ghassan Kanafani's 'Letter From Gaza.'” The mentioned novel is Berger's From A to X: A Story in Letters (London: Verso, 2008).

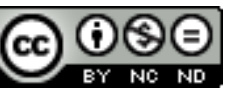

Creative Commons Attribution-NonCommercial-NoDerivatives 4.0 International License 